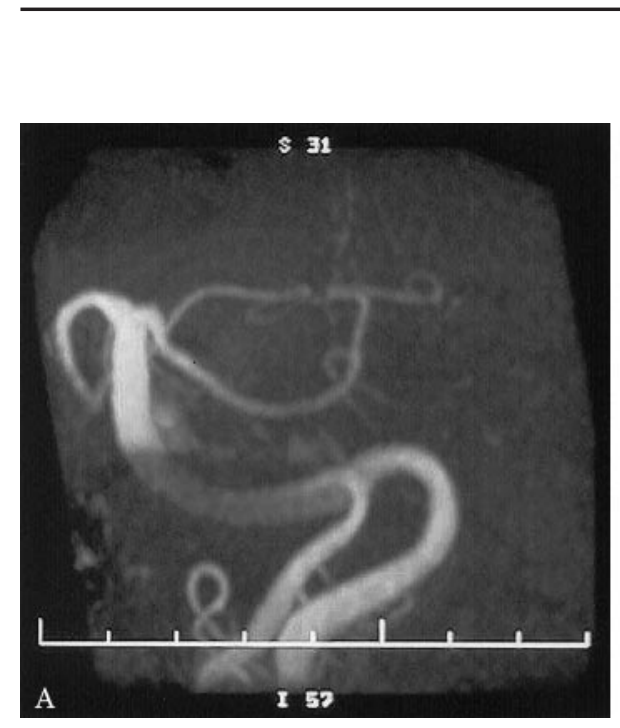

Neuro Images
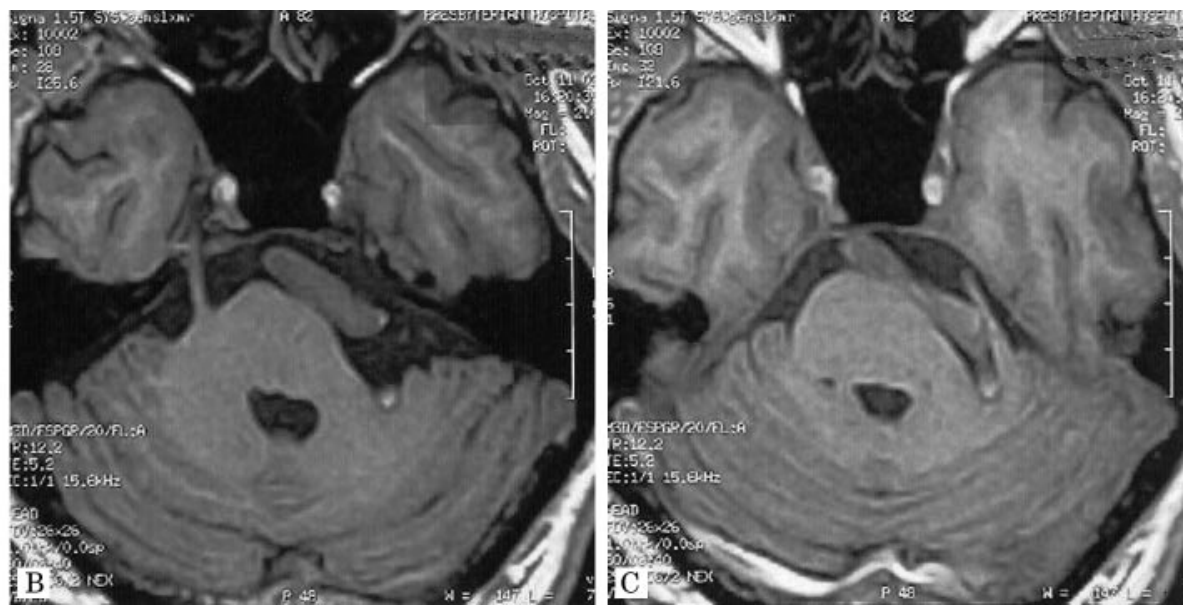

Figure. MR angiogram of the vertebrobasilar system shows basilar artery ectasia (A). Axial T1-weighted images show elongated and tortuous basilar artery with pressure effect on left trigeminal nerve (C). The right trigeminal nerve shows no pressure effect $(B)$.

\section{Tic doulereux in basilar artery ectasia}

Hamid Sami, MD, MSc, Calin I. Prodan, MD, Oklahoma City, OK

A 60-year-old man presented with intermittent left-sided lancinating facial pain for the past 6 months, without an identifiable trigger. General physical examination results were normal. Neurologic examination showed only decreased touch sensation in left

Address correspondence and reprint requests to Dr. Hamid Sami, Dept. of Neurology, University of Oklahoma Health Science Center, P.O. Box 26901, Suite 215, Oklahoma City, OK 73190-3048; e-mail: hamid-sami@ouhsc.edu
V3 distribution. MRI of the brain followed by MR angiogram showed marked basilar artery ectasia with evidence of direct pressure on the left trigeminal nerve (figure). Basilar artery ectasia has been associated with cranial neuropathies, hydrocephalus, and ischemic symptoms in the vertebro-basilar distribution. ${ }^{1} \mathrm{MR}$ imaging and angiography represent a valuable noninvasive diagnostic tool for this arterial abnormality. In our case, treatment with carbamazepine produced marked symptomatic improvement. Microvascular decompression or gamma knife radiosurgery may be helpful if medical treatment fails.

1. Levine RL, Turski PA, Grist TM. Basilar artery dolichoectasia. Review of the literature and six patients studied with magnetic resonance angiography. J Neuroimaging 1995;5:164-170. 


\title{
Neurology
}

\author{
Tic doulereux in basilar artery ectasia \\ Hamid Sami and Calin I. Prodan \\ Neurology 2003;61;713 \\ DOI 10.1212/WNL.61.5.713
}

This information is current as of September 8, 2003

\section{Updated Information \&} Services

References

Permissions \& Licensing

Reprints including high resolution figures, can be found at: http://n.neurology.org/content/61/5/713.full

This article cites 1 articles, 0 of which you can access for free at: http://n.neurology.org/content/61/5/713.full\#ref-list-1

Information about reproducing this article in parts (figures,tables) or in its entirety can be found online at:

http://www.neurology.org/about/about_the_journal\#permissions

Information about ordering reprints can be found online: http://n.neurology.org/subscribers/advertise

Neurology ${ }^{\circledR}$ is the official journal of the American Academy of Neurology. Published continuously since 1951, it is now a weekly with 48 issues per year. Copyright . All rights reserved. Print ISSN: 0028-3878. Online ISSN: 1526-632X.

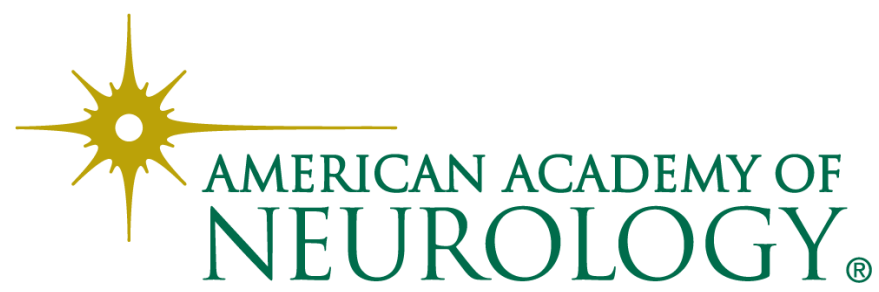

